\title{
KETERBUKAAN DAN NIAT: REFLEKSI TERHADAP GEJALA SIMBOLISME DALAM MASYARAKAT ISLAM PASCA-KEBENARAN
}

\author{
Widia Febriana \\ Aisyah_al_hadid@yahoo.co.id \\ (UIN Syarif Hidayatullah, Jakarta, Indonesia) \\ Tayo Sandono \\ Penulismemori@gmail.com \\ (UIN Sunan Gunung Djati, Bandung, Indonesia)
}

\begin{abstract}
Abstrak
Simbolisme dalam arti yang sempit khusus untuk artikel ini adalah pemakaian ikon dan simbol untuk menjustifikasi suatu perbuatan yang sebenarnya dapat dievaluasi secara rasional dengan menyorot langsung pada fakta perbuatan tersebut.Contoh dari simbolisme adalah penokohan terhadap seseorang. Simbolisme terlihat pada masyarakat Islam kontemporer sebagai sebuah gejala dalam pergaulan sosial dimana masyarakat menggunakan simbol dan ikon untuk menjustifikasi perbuatan-perbuatan yang dinilai amoral atau pidana dari perspektif sebagian masyarakat, muslim atau non-muslim. Tujuan pertama makalah ini adalah untuk meninjau ajaran Islam mengenai simbolisme dengan latar belakang evolusioner dan sejarah kenabian.Tujuan kedua makalah ini adalah menawarkan solusi atas masalah simbolisme dengan berpijak pada ajaran Islam.Kami menggunakan metode intuisi linguistik dari bidang filsafat analitik untuk mencapai kedua tujuan tersebut.Hasil analisis menunjukkan bahwa simbolisme adalah sebuah naluri purba manusia yang terus ditentang oleh nabi-nabi dari Adam hingga Muhammad.Simbolisme memunculkan bahaya bagi kelangsungan hidup manusia karena dapat membawa pada perpecahan dan adu domba oleh pihak ketiga sehingga tanpa kesadaran bahwa dirinya telah diperalat, manusia menjalankan agenda-agenda pihak ketiga.Untuk mengatasi masalah ini, kami menawarkan dua solusi.Pertama, solusi vertikal dengan merujuk langsung pada niat dari pelaku dalam melakukan perbuatan.Kedua, solusi horizontal dengan melakukan diskusi dan silaturahmi antar kelompok.
\end{abstract}

\section{Kata kunci:simbolisme, niat, kemunafikan, ikon, perpecahan}

\begin{abstract}
Symbolism in a narrow sense specifically for this article is the use of icons and symbols to justify an action which can actually be evaluated rationally by highlighting the facts of the action. Examples of symbolism are characterization of a person. Symbolism is seen in contemporary Islamic society as a symptom in social interactions where people use symbols and icons to justify actions that are considered immoral or criminal from the perspective of some people, Muslim or non-Muslim. The first objective of this paper is to review the Islamic teachings regarding symbolism against an evolutionary background and prophetic history. The second purpose of this paper is to offer a solution to the problem of symbolism based on Islamic teachings. We employ methods of linguistic intuition from the field of analytic philosophy to achieve both goals. The results of the analysis show that symbolism is an ancient human instinct that was constantly opposed by the prophets from Adam to
\end{abstract}


Muhammad. Symbolism poses a danger to human survival because it can lead to division and manipulation by third parties to carry out their own agenda. To solve this problem, we offer two solutions. First, a horizontal solution by conducting deliberation and friendship between groups.Second, the vertical solution by referring directly to the perpetrator's intention to do the action.

\section{Keywords: symbolism, intention, hypocrisy, icon, division}

\section{Pendahuluan}

Manusia semenjak zaman batu tua (paleolitikum).telah menggunakan ikon dan simbol dalam kehidupannya seharihari. ${ }^{1} \quad$ Manusia adalah mahluk yang mengandalkan mata untuk menavigasi dan bertahan hidup di lingkungannya.Manusia saling mengenal sesama dengan mengidentifikasi wajah, bukan bau.Ketika ketiadaan penampakan, misalnya dalam gelap gulita, manusia menjadi waspada dengan bahaya. ${ }^{2}$ Bulu-bulu halus di tubuh manusia menegang, detak jantung meningkat, dan nafas terengah-engah untuk menandakan kewaspadaan tersebut.Mata manusia menjadi sangat sensitif ketika gelap untuk mendapatkan secercah cahaya dan petunjuk visual dalam menjaga hidupnya dari ancaman.

Karena kebertopangan ini, manusia membentuk hal-hal yang sejatinya tak berwujud. ${ }^{3}$ Angin, gempa, hujan lebat, dan berbagai gejala alam yang dapat

${ }^{1}$ Pierce mengenal tiga konsep: ikon, indeks, dan simbol. Ikon adalah sebuah wujud fisik yang tampak, indeks adalah relasi-relasi ikon di dalam ruang dan waktu, sementara simbol adalah relasi antara ikon, indeks, dan manusia sebagai penafsirnya. Proses penafsiran sesuatu mengalami progresi dari ikon menjadi indeks dan akhirnya menjadi simbol bagi manusia (Barham \& Everett, 2020, hlm. 2; Greenberg, 2018, hlm. 164).

${ }^{2} \mathrm{M}$ Clasen, 'Evolutionary Study of Horror Literature', in The Palgrave Handbook to Horror Literature, ed. K Corstorphine and L Kremmel (London: Palgrave Macmillan, 2018), 4.

${ }^{3}$ Nicholas Epley, 'A Mind like Mine: The Exceptionally Ordinary Underpinnings of Anthropomorphism', Journal of the Association for Consumer Research 3, no. 4 (2018): 1. mengancam nyawa manusia dipersonifikasikan menjadi mahlukmahluk individual (antropomorfisme). ${ }^{4}$ Manusia bahkan membuat persona ini menjadi nyata dalam bentuk berhala agar mudah diamati dan 'dijinakkan'.Lalu muncullah patung-patung sebagai personifikasi kekuatan alam yang dapat mengancam hidup manusia dan dapat dikendalikan pula oleh manusia.

Tokoh-tokoh manusia juga dapat menjadi ikon jika mereka memiliki kemampuan yang luar biasa.Para kepala suku pada umumnya adalah alpha, yaitu orang yang menonjol dalam kelompok karena kemampuannya.Para tokoh alpha ini kemudian ditakuti jika menjadi lawan, dan disegani dan dihormati jika menjadi pelindung. Status mereka dapat diangkat menjadi level dewa dan dijadikan sembahan. Ikon-ikon ini kemudian dipelihara dan praktik pemeliharaannya diwariskan dari generasi ke generasi. ${ }^{5}$ Sebuah peristiwa alam yang terjadi bersamaan perilaku tertentu terhadap ikon ditafsirkan sebagai penerimaan dewa dan alpha terhadap perilaku manusia dan begitu juga, peristiwa nahas yang terjadi bersamaan dengan perilaku tertentu terhadap ikon ditafsirkan sebagai kemarahan dewa dan alpha terhadap

4 Domenica Bruni, Pietro Perconti, and Alessio Plebe, 'Anti-Anthropomorphism and Its Limits', Frontiers in Psychology 9, no. 2205 (2018): 1.

5 P Kiernan, Roman Cult Images: The Lives and Worship of Idols from the Iron Age to Late Antiquity (Cambridge: Cambridge University Press, 2020), 19. 
perilaku manusia.Relasi-relasi yang dipandang absurd oleh manusia saat ini, dapat dipandang sangat masuk akal pada alam pikiran masa lalu yang memiliki pengetahuan sangat terbatas mengenai gempa, dinamika meteorologis, atau hidrologi.

Tradisi turun temurun ini kemudian menjadi identitas ketika kelompokkelompok manusia saling bertemu dalam pergaulan lintas kelompok.Mereka tidak berpikir kalau semua diatur oleh satu kekuasaan agung. Mereka cukup berpikir bahwa ikon mereka telah terbukti melindungi kelompok mereka sendiri dan tidak kelompok lain. Akibatnya, kita dapat melihat Ka'bah di masa jahiliyah adalah sebuah dunia multi-ikon dengan aneka berhala dan leluhur yang melambangkan identitas dari suku-suku yang ada.Dalam bahasa William James, berhala-berhala tersebut adalah diri diperluas (extended self).dari anggota-anggota suku yang memuja mereka. ${ }^{6}$ Penokohan yang dipuja tersebut adalah perpanjangan eksistensi dari pendukungnya.

Kemampuan berpikir juga mengalami evolusi dan hal ini datang belakangan setelah manusia memiliki sensitivitas visual. ${ }^{7}$ Kemampuan berpikir abstrak adalah anugerah besar dari Tuhan yang memungkinkan manusia dapat memahami ruang lingkup dunia melebihi

${ }^{6}$ JL Pierce and J Peck, 'The History of Psychological Ownership and Its Emergence in Consumer Psychology', in Psychological Ownership and Consumer Behavior, ed. Joann Peck and Suzanne B Shu (Cham, Switzerland: Springer, 2018), 2.

${ }^{7}$ A Tager, "The Triple "I " and the Human Eye: Three Phases of Evolution in Vision and Thinking', New Zealand Online Journal of Interdisciplinary Studies 1, no. 3 (2019): 89; P Taylor et al., 'The Global Landscape of Cognition : Hierarchical Aggregation as an Organizational Principle of Human Cortical Networks and Functions', Scientific Reports 5, no. 18112 (2015): 7. dari apa yang tampak oleh mata dan membuat refleksi diri, memprediksi, dan berkreasi. ${ }^{8}$ Kemampuan yang bertopang pada daya kognitif otak ini telah membuahkan kodifikasi pengetahuan dalam berbagai wujudnya maupun alat-alat kompleks dan tata kelola sosial yang membantu manusia dalam menghadapi permasalahan hidup dan bertahan hidup. ${ }^{9}$

Walaupun secara alamiah manusia akan mengumpul di sekitar alpha, yang mejadi alpha karena kekuatan, kekayaan, atau kecerdasannya, akal yang muncul kemudian menimbang untung rugi dan rasionalitas dari kecenderungankecenderungan ini. Kecenderungan untuk takut pada sesuatu akan dinilai benar tidak atau baik buruknya oleh akal lewat rasionalitas dan prinsip-prinsip yang diajarkan dan dievaluasi lintas generasi. Kesukaan pada alpha dan fanatisme untuk mendorong eksistensi individual/kelompok juga dievaluasi oleh akal.Jelas bahwa akal telah mampu menggantikan naluri dalam mendorong kelangsungan hidup manusia dan karenanya, diutamakan seiring berjalannya waktu.Dengan adanya akal, manusia tidak lagi semestinya memahami tanda alam sebagai tanda-tanda partikular, terlebih karena adanya saling kait mengait antara gejala alam yang satu dengan yang lain lewat hukum kausalitas.

Masalahnya kemudian adalah pada masa sekarang, ikon masih digunakan sebagai justifikasi atas perbuatanperbuatan tertentu yang semestinya dijustifikasi secara rasional oleh akal.Akal adalah anugerah Tuhan pada manusia yang lebih kompleks dan ampuh dalam

${ }^{8}$ Floortje E Scheepers et al., 'Psychosis as an Evolutionary Adaptive Mechanism to Changing Environments', Frontiers in Psychiatry 9, no. 237 (2018): 1.

${ }^{9}$ Saurabh Srinivasan et al., 'Enrichment of Genetic Markers of Recent Human Evolution in Educational and Cognitive Traits', Scientific Reports 8, no. 12585 (2018): 2. 
membangun peradaban daripada ikon, tetapi manusia seringkali menggunakan ikon sebagai sumber justifikasi karena lebih efisien dan efektif dalam mengantarkan pesan walaupun tidak memberikan nilai kebenaran karena sepenuhnya diasumsikan dan bahkan irasional. $^{10}$

Masalah lain dari penggunaan ikon adalah bahwa ikon, dan simbol, dapat dimanipulasi dengan mudah oleh kepentingan-kepentingan

tersembunyi.Sedemikian jauhnya manusia menggunakan ikon/simbol sehingga ikon/simbol dapat dimanfaatkan oleh pihak lain untuk kepentingan manipulatif. Sebagai contoh simbol yang dapat dimanipulatif adalah perilaku berbicara lemah lembut. Masyarakat terlanjur mengasosiasikan ramah tamah dengan moral yang baik padahal bahkan penjahatpun berbicara lemah lembut ketika akan menipu korbannya. Koruptor juga ramah dengan orang lain, begitu pula kapitalis yang ingin mengeksploitasi konsumen atau masyarakat sekitar. Bahkan ketika membujuk Adam memakan buah khuldi, Iblis berbicara dengan lemah lembut.Kita dapat membayangkan kapitalisme yang menjustifikasi pelanggaran hak asasi manusia menggunakan simbol kesejahteraan, keberlanjutan, atau kebangsaan, sementara reformasi yang mendorong keadilan sosial dapat diartikan sebagai perusak perdamaian.

Para peneliti di bidang sosial dan komunikasi mengistilahkan masa kini sebagai masa 'pasca-kebenaran' yaitu masa dimana orang-orang bertopang lebih pada hal-hal yang tampak, ikon, dan simbol ketimbang kebenaran dari sesuatu. Pada era pasca kebenaran, kebohongan

\footnotetext{
${ }^{10}$ Bryce Morsky and Erol Akcay, 'Evolution of Social Norms and Correlated Equilibria', PNAS 116, no. 18 (2019): 5.
}

diindustrialisasikan dan muncul industri yang menciptakan dan mendiseminasi kebohongan untuk memenuhi kepentingan bisnis dan ideologis dan secara strategis menyembunyikan kebenaran, membingungkan publik, dan menciptakan kontroversi. ${ }^{11}$ Pada era pasca kebenaran, kebohongan dan kesalah-pahaman menjadi strategi penting untuk mencapai tujuan tanpa terlihat sebagai orang yang dianggap tidak bermoral bermoral. ${ }^{12}$ Termasuk faktor yang sangat mendukung hal ini adalah bias konfirmasi yang terjadi akibat teknologi informasi maupun oleh hasrathasrat manusia yang ingin memperoleh keuntungan secara cepat. ${ }^{13}$

Arsitek pasca kebenaran mengeksploitasi ikon dan simbol untuk melayani ideologi dan bisnis. Sebagai contoh, para peternak, politisi, agamawan, wartawan, dan ilmuan saat ini terlibat dalam perang simbol antara dua pihak: pendukung makan daging dan pendukung vegetarianisme. Pendukung makan daging mengangkat simbol kekuatan, kesuburan, dan maskulinitas, sementara vegetarian mengangkat simbol kedamaian, kesehatan, dan keberlanjutan, keduanya berangkat dari ikon daging dan sayur-buah. ${ }^{14}$ Media secara teratur dan sistematis mengangkat mitos Barthesian, yaitu menggunakan foto

11 Ziauddin Sardar, 'The Smog of Ignorance: Knowledge and Wisdom in Postnormal', Futures 120 (2020): 5, https://doi.org/10.1016/j.futures.2020.102554.

12 Pablo Valdivia, 'Narrating Crises and Populism in Southern Europe: Regimes of Metaphor', Journal of European Studies 49, no. 34 (2019): 296.

${ }^{13}$ Pelle G Hansen, Vincent F Hendricks, and RK Rendsvig, 'Infostorms', Metaphilosophy 44, no. 3 (2013): 303; Laurence T Hunt et al., 'Approach-Induced Biases in Human Information Sampling', PloS Biology 14, no. 11 (2016): 9.

${ }^{14}$ Frederic; Leroy et al., 'Meat in the PostTruth Era . Mass-Media Discourses on Health and Disease in the Attention Economy', Appetite 125 (2018): 349. 
dan video sebagai simbol atas apa yang ingin mereka sampaikan kepada publik, tanpa peduli realitas sesungguhnya pada saat foto dan video tersebut tersebut dibentuk. ${ }^{15}$ Para wartawan dapat dijadikan mesin politik dengan mengeksploitasi kemampuan mereka dalam menggunakan ikon dan simbol untuk membujuk publik. ${ }^{16}$

Jelas lah bahwa ikon dan simbol dapat digunakan untuk mengadu domba umat dan menghilangkan persatuan di kalangan umat Muslim maupun antara umat Muslim dengan umat-umat lainnya. Kasus Charlie Hebdo dengan ikon kartun Nabi Muhammad, kasus Rizieq Syihab atau wacana relasi Islam dan terorisme dengan ikon WTC adalah tiga contoh besar mengenai bagaimana ikon dan simbol menjadi senjata yang mampu memecah belah sesama kelompok di dalam umat Islam maupun hubungan baik umat Islam dengan umat-umat lainnya.

Dimasa ini keberadaan Covid-19 adalah sebuah momen yang sangat penting untuk mengedukasi publik bahwa suatu aspek dalam masalah memiliki akar yang tidak tampak. Bahwa Covid-19 memungkinkan adanya hikmah bahwa kita perlu berorientasi pada sesuatu yang tidak tampak dan evolusi masa depan manusia perlu diarahkan pada identifikasi hal-hal yang tak terlihat sebagai ancaman yang nyata ketimbang ikon dan simbol yang terlihat. Tetapi kesempatan ini tampaknya telah lepas karena publik masih terlihat tidak terlalu patuh pada protokol kesehatan

15 N Lackovic, 'Thinking with Digital Images in the Post-Truth Era: A Method in Critical Media Literacy', Postdigital Science and Education 2 (2020): 455.

${ }^{16}$ Matt Carlson, 'The Information Politics of Journalism in a Post- Truth Age', Journalism Studies 19, no. 13 (2018): 8, https://doi.org/10.1080/1461670X.2018.1494513. dan kasus terus bertambah dari waktu ke waktu. ${ }^{17}$

Ajaran Islam bersifat universal dalam konteks ruang dan waktu sehingga tidak ada kata terlambat untuk diterapkan dan diambil hikmahnya untuk menghadapi masalah simbolisme. Ajaran Islam dapat memberikan solusi atas permasalahan simbolisme dengan menggali pada doktrin maupun aspek-aspek normatif dan etik yang diajarkan Islam.

Berdasarkan latar belakang di atas, permasalahan yang akan diangkat dalam artikel ini adalah bagaimana sikap kita terhadap ikonisme dan simbolisme? Dan bagaimana kita dapat mencegah diri dimanfaatkan oleh pihak ketiga untuk tujuan batil?

\section{Metode Penelitian}

Studi akademis di bidang filsafat saat ini pada dasarnya terbagi ke dalam empat tradisi yaitu tradisi filsafat analitik, tradisi filsafat pikiran, tradisi filsafat logika, dan tradisi filsafat bahasa. ${ }^{18}$ Filsafat analitik membedah suatu masalah dengan memecahnya menjadi elemen-elemen yang lebih sederhana dan jelas. Hal ini berbeda dari tradisi lain yang membawa masalah pada isu psikologis, logis, atau bahasa. Artikel ini berangkat dari tradisi filsafat analitik dengan memandang permasalahan simbolisme sebagai sebuah permasalahan kompleks yang dapat menjadi terang dan jelas dengan menariknya ke konsep yang lebih mendasar.

Terdapat empat pendekatan metodologi studi dalam filsafat analitik, yaitu pendekatan analisis konseptual, pendekatan intuisi linguistik, pendekatan

17 E Suhaeni, 'Manusia Dan Ancaman Covid-19 Dalam Perspektif Al- Qur'an', Rausyan Fikr 16, no. 2 (2020): 114.

${ }^{18}$ Mudasir Ahmad Tantray, Tariq Rafeeq Khan, and ID Rather, 'Nature of Analytical Philosophy', Ravenshaw Journal of Philosophy 6 (2020): 16. 
eksperimen pikiran, dan pendekatan empiris. ${ }^{19}$ Kami menggunakan pendekatan intuisi linguistik dalam studi ini. Pendekatan intuisi linguistik berpijak pada kemampuan filsuf untuk menggunakan semua daya pikir dan pengalaman yang telah diperolehnya dalam memahami sejarah dan isu-isu filsafat untuk membedah suatu permasalahan. ${ }^{20}$ Pendekatan ini menurut kami sesuai dengan permasalahan simbolisme karena terkait erat dengan kompetensi kami di bidang filsafat Islam.

Kami menerapkan pendekatan intuisi linguistik dengan membedah permasalahan simbolisme ke dalam sejarah Islam dengan melihat kasus-kasus simbolisme dalam sejarah kenabian, khususnya kenabian Muhammad SAW.Setelah tinjauan historis ini, kami membawa permasalahan simbolisme pada aspek kontemporer dengan membawa pemahaman ilmiah terhadap simbolisme dan dampaknya bagi kehidupan sosial. Terakhir, kami menawarkan solusi atas simbolisme dengan menonjolkan pemakaian akal berdasarkan dua prinsip utama: keterbukaan dalam menganalisis peristiwa dan evaluasi peristiwa berdasarkan niat.

\section{Hasil dan Pembahasan}

\subsection{Simbolisme dan Berhala}

Semenjak awal sejarah nabi-nabi, dimulai dari Adam AS, simbolisme telah digunakan sebagai justifikasi atas perbuatan. Saat diminta untuk sujud di depan Adam, iblis menolak karena dirinya diciptakan dari api yang dianggap lebih

19 A-M A Eder, Lawler Raphael, and R van Riel, 'Philosophical Methods under Scrutiny: Introduction to the Special Issue Philosophical Methods', Synthese 197, no. 3 (2020): 915, https://doi.org/10.1007/s11229-018-02051-2.

20 Miguel Egler and Lewis D Ross, 'Philosophical Expertise under the Microscope', Synthese 197, no. 3 (2020): 1078, https://doi.org/10.1007/s11229-018-1757-0. mulia dari Adam yang diciptakan dari tanah. Iblis menggunakan falasi genetik, dimana dalam membuat alasan, alasan yang digunakan adalah alasan silsilah atau keturunan. $^{21}$ Alasan keturunan adalah sebuah falasi karena tidak menempatkan kebenaran pada konteksnya tetapi pada sebuah sumber yang tidak relevan. ${ }^{22}$ Falasi genetik adalah sebuah simbolisme, dengan merujuk suatu ikon yang diagungkan, yaitu api, dan simbol yang dianggap hina, yaitu tanah. Indikator lain dari pemuliaan simbol adalah penggunaan falasi otoritas yang tidak layak (inappropriate appeal to authority).dimana pihak yang berkuasa seperti pemerintah dianggap benar atau baik. $^{23}$

Nabi Ibrahim AS berjuang mempertaruhkan nyawanya dengan menghancurkan simbol-simbol yang digunakan masyarakat untuk disembah.Jelas bahwa ketika diajak berargumen, kaum Namrud yang menyembah berhala menggunakan falasi genetik dengan menyatakan bahwa nenek moyang mereka telah melakukan hal seperti ini sejak lama. Tidak ada argumen yang rasional untuk menegaskan bahwa menyembah berhala lebih menguntungkan atau baik bagi masyarakat dibandingkan menyembang Tuhan yang Esa. Hal ini telah mencerminkan adanya kultus, bukannya rasionalitas yang ada di dalam ajaran.

\footnotetext{
${ }^{21}$ Charles L Barzun, 'The Genetic Fallacy and a Living Constitution', Constitutional Commentary 34 (2019): 429.

22 F Scalambrino, 'Genetic Fallacy', in Bad Arguments: 100 of the Most Importan Fallacies in Western Philosophy, ed. R Arp, S Barbone, and M Bruce (Oxford: Wiley Blackwell, 2019), 160.

${ }^{23}$ Nicolas Michaud, 'Inappropriate Appeal to Authority', in Bad Arguments: 100 of the Most Importan Fallacies in Western Philosophy, ed. R Arp, S Barbone, and M Bruce (Oxford: Wiley Blackwell, 2019), 168.
} 
Nabi Muhammad SAW memberikan gambaran sebuah perjuangan tak henti dalam menghilangkan ikon-ikon yang disembah manusia.Ketika Nabi Muhammad SAW menaklukkan Mekkah, ikon-ikon yang ada di dalam dan sekitar Ka'bah dihancurkan dan semenjak itu, tidak ada lagi penyembahan terhadap ikon dilakukan di Mekkah. Saat Nabi Muhammad SAW akan meninggal dunia, ia berpesan agar kuburnya tidak dibangunkan masjid di atasnya sehingga dapat menjadi ikon baru yang mempersekutukan Allah. Sejalan dengan ini, ketika Nabi wafat, Abu Bakar berkata pada umat Islam dengan menyebutkan ayat QS Ali Imron[3]:144: QS. Ali Imron[3]:144. Muhammad itu tidak lain hanyalah seorang rasul, sungguh telah berlalu sebelumnya beberapa orang rasul. Apakah jika Dia wafat atau dibunuh kamu berbalik ke belakang (murtad).? Barangsiapa yang berbalik ke belakang, Maka ia tidak dapat mendatangkan mudharat kepada Allah sedikitpun, dan Allah akan memberi Balasan kepada orang-orang yang bersyukur. Abu-Bakar mengatakan setelah mengucapkan ayat tersebut bahwa: "barang siapa menyembah Muhammad, ketahuilah, bahwa Muhammad telah wafat barang siapa menyembah Allah, ketahuilah Allah hidup selamanya". ${ }^{24}$

Pada masa para nabi, terdapat tiga kelompok penyembah simbol.Pertama, kelompok yang sepenuhnya menyembah ikon dan tidak mengenal Allah.Kelompok ini misalnya adalah masyarakat di masa Ibrahim. $^{25}$ Kedua, kelompok yang menyembah ikon sekaligus menyembah Allah.Kelompok ini misalnya sebagaimana yang dirujuk dalam QS. Al-Baqarah[2]:165

24 Warjo, Vita Dhameria, and Judiman, 'Agama Islam Sebagai Tata Nilai Kehidupan Bisnis Ber-Etika', Cendekia Jaya 1, no. 2 (2019): 9.

${ }^{25}$ QS. Ibrahim[21[:52 sebagai kelompok yang mencintai tandingan-tandingan Allah sebagaimana mereka mencintai Allah. Kelompok ketiga adalah kelompok yang menyembah Allah ketika menghadapi kesusahan yang amat sangat, lalu menyembah simbol ketika mereka bersenang-senang. ${ }^{26}$ Kelompok ketiga ini merupakan kelompok yang dominan di masa modern ini di kalangan umat Islam. Mereka kembali di kala susah kepada Allah, sementara di masa senang, mereka kembali pada ikon-ikon dalam kehidupan sehari-hari seperti harta, permainan, dan sebagainya.

Falasi genetik tidaklah langsung bermakna bahwa seseorang menyembah keturunan. Iblis tidak menyembah api, tetapi dengan memandang api lebih mulia dari tanah sebagai pijakan argumentasi, berarti membawahkan otoritas Tuhan yang mengabaikan asal usul sebagai justifikasi untuk bersujud di depan Adam. Ia menyimpangkan dari alasan yang rasional yang semestinya dapat diajukan untuk menolak bersujud di depan Adam. Malaikat misalnya, menolak dengan alasan yang rasional, yaitu bahwa Adam akan membuat kerusakan di muka Bumi karena sifat-sifatnya sehingga tidak layak dihormati malaikat. Untuk ini, Allah hanya mengatakan bahwa Ia lebih tahu daripada malaikat.

Dari gambaran historis di atas, kita dapat melihat adanya potensi progresif dari ikon/simbol menjadi berhala.Jika seseorang terlalu mencintai dan memuliakan ikon, maka orang tersebut dapat terjerumus ke dalam syirik.

\footnotetext{
${ }^{26}$ QS. Az-Zumar[39]:8, QS. Al Ankabut[29]:65
} 


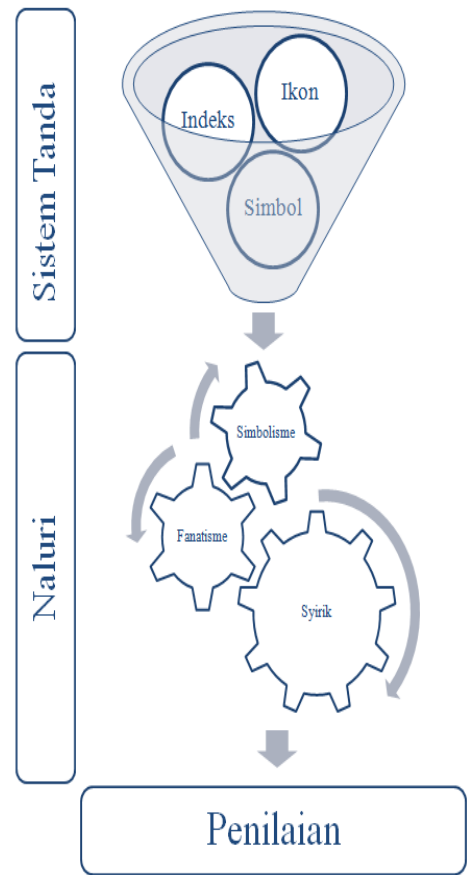

Gambar 1 Penilaian Perbuatan Berbasis Naluri dengan Simbolisme

Gambar 1 memberikan tinjauan mengenai sistem tanda yang diperlukan untuk membawa pada naluri dan bermuara pada penilaian berbasis simbolisme. Gambar ini menunjukkan sistem tanda dalam bentuk ikon, indeks, dan simbol membawa pada naluri manusia akan simbolisme, yang dapat membawa lebih lanjut pada fanatisme dan bahkan syirik. Ketiga hal ini dapat bekerja sendiri-sendiri atau secara kolektif membentuk penilaian terhadap sesuatu secara irasional dan mengandung berbagai bias kognitif seperti misalnya falasi genetik atau falasi otoritas yang salah.

Simbolisme juga memungkinkan pihak ketiga memanfaatkan simbol untuk memanipulasi manusia demi eksistensi mereka.Kaum munafik sangat memahami hal ini.Mereka dapat berbicara bahwa kita harus berperilaku lemah lembut, tetapi di sisi lain, terjadi ironi ketika mereka tersenyum ketika lawan yang mereka kritik karena berperilaku kasar, akhirnya terluka dan bahkan meninggal dunia.Jika seseorang yang telah dinisbahkan kasar lalu berbicara kasar, maka hal ini sudah suatu kewajaran dan konsistensi. Sementara itu, jika seseorang yang telah dinisbahkan baik lalu mensyukuri kematian orang yang tidak ia sukai, tentunya hal ini adalah kontradiktif dan karenanya, dapat dikatakan munafik.Kapitalis sering menggunakan ikon warna hijau sebagai simbol keberlanjutan untuk menjustifikasi kerusakan alam yang ditimbulkannya. Penjahat dapat menggunakan simbol pakaian serba putih untuk mengaburkan perilaku bejat dan jahat yang ia lakukan sementara aksi nahi mungkar dapat dikatakan sebagai premanisme. Pada masa G30S, ribuan nyawa hilang karena di cap sebagai PKI, tanpa ada bukti nyata bahwa mereka benar-benar PKI.

Untuk itu, menjadi sangat penting bagi umat Islam untuk mengambil langkah anikonisme, yaitu menghilangkan ikonikon dalam kehidupan sehari-hari.Hal ini dilakukan misalnya dengan tidak membuat patung, menghilangkan wajah para nabi dari ilustrasi, atau tidak menggunakan wujud manusia dan hewan dalam bangunan.Salah satu ciri penentu yang membedakan arsitektur Islam dengan arsitektur lainnya adalah anikonisme di dalam bangunan, dimana tidak dapat ditemukan adanya figur manusia dan hewan dalam ilustrasi maupun konstruksi bangunan. $^{27}$

Hal yang lebih tak kalah pentingnya lagi adalah menggunakan akal untuk memandu kehidupan. ${ }^{28}$ Akal memberi

27 Recep Dogan, 'The Soul's Need to Connect with God through the Language of Art: Analysis from an Islamic Perspective', Review of European Studies 10, no. 2 (2018): 61.

28 Widia Febriana and Tayo Sandono, 'Relativisme Determinatif: Akal, Sistem, Dan Waktu Sebagai Komponen Quranik Untuk Optimalisasi Hidup Manusia', Aqlania: Jurnal Filsafat dan Teologi Islam 11, no. 2 (2020): 9. 
tahukan bahwa jika kita hanya menghormati dan bahkan mengidolakan pihak yang kuat, tidak akan muncul keadilan karena pihak yang kuat dapat menerapkan kekuasaannya lewat paksaan. Akal menjadikan setiap orang adalah khalifah sebagai agen yang bebas dan mandiri.Akal membebaskan manusia dari kecenderungan mengikuti alpha dan dimanipulasi oleh para pengguna simbol.Akal membuat manusia dalam memilih dan memilah mana kecenderungan evolusioner yang sesuai dengan tempatnya dan mana yang perlu ditekan, kapan waktu untuk berjuang dan kapan waktu untuk berserah diri.Akal melepaskan manusia dari belenggu naluri.Akal menjadikan kita memandang Nabi Muhammad sebagai manusia biasa yang kebaikannya ada pada ajaranNya, bahwa Nabi Muhammad SAW bukan dewa atau Tuhan, dan bahwa Ka'bah tidak lebih dari sekedar orientasi, bukan sebagai berhala yang disembah. Akal juga yang akan mengorientasikan pemecahan masalah ke arah nilai dan makna serta substansi, ketimbang permasalahan simbolik yang bersifat kulit (permukaan).dan tidak solutif serta memungkinkan kemunafikan terkamuflase dalam perilaku tampak.Hal ini sejalan dengan pemikiran Sayyed Hossein Nasr bahwa agama tidak berhenti pada simbolisme tetapi memasuki substansi. ${ }^{29}$

Dengan adanya akal, manusia tidak lagi semestinya memahami tanda alam sebagai tanda-tanda partikular, terlebih karena adanya saling kait mengait antara gejala alam yang satu dengan yang lain lewat hukum kausalitas. Hal ini semestinya dimungkinkan lewat adanya satu hukum tunggal dan karenanya, satu Tuhan yang

${ }^{29} \mathrm{~J}$ Harahap, 'Sayyed Hossein Nasr Tentang Filsafat Perennial Dan Human Spiritualitas', Aqlania: Jurnal Filsafat dan Teologi Islam 08, no. 02 (2017): 183. tidak dapat dipersepsi oleh mata yang terbatas. Betapa pentingnya akal bagi memahami alam dapat dilihat dalam ayatayat berikut:

QS. Ar-Rum[30]:21-24. dan di antara tanda-tanda kekuasaan-Nya ialah Dia menciptakan untukmu isteri-isteri dari jenismu sendiri, supaya kamu cenderung dan merasa tenteram kepadanya, dan dijadikan-Nya diantaramu rasa kasih dan sayang. Sesungguhnya pada yang demikian itu benar-benar terdapat tanda-tanda bagi kaum yang berfikir; dan di antara tandatanda kekuasaan-Nya ialah menciptakan langit dan bumi dan berlain-lainan bahasamu dan warna kulitmu.Sesungguhnya pada yang demikan itu benar-benar terdapat tanda-tanda bagi orang-orang yang mengetahui; dan di antara tanda-tanda kekuasaan-Nya ialah tidurmu di waktu malam dan siang hari dan usahamu mencari sebagian dari karuniaNya.Sesungguhnya pada yang demikian itu benar-benar terdapat tandatanda bagi kaum yang mendengarkan; dan di antara tanda-tanda kekuasaan-Nya, Dia memperlihatkan kepadamu kilat untuk (menimbulkan).ketakutan dan harapan, dan Dia menurunkan hujan dari langit, lalu menghidupkan bumi dengan air itu sesudah matinya. Sesungguhnya pada yang demikian itu benar-benar terdapat tandatanda bagi kaum yang mempergunakan akalnya.

Ayat di atas menunjukkan keutamaan akal bagi manusia dalam mempertahakan hidupnya pada lingkungan alam sekitarnya.Perhatikan bahwa pada keempat ayat ini, fenomena yang dirujuk adalah gejala alam yang positif seperti hubungan interpersonal, hubungan antar kelompok, siklus kehidupan sehari-hari, dan kehidupan di bumi. Fenomena-fenomena positif ini adalah kondisi yang kondusif bagi penggunaan akal tanpa tekanan sehingga akal dapat dimanfaatkan secara maksimal lewat proses berpikir, 
mengetahui, mendengarkan, dan menggunakan akalnya. Abstraksi dari hasil berpikir dalam situasi positif ini semestinya akan membawa pada kesadaran Tauhid dan menggunakan kesadaran tersebut untuk mengembangkan sistem antisipasi jika situasi negatif terjadi, yang jika tanpa akal, dikendalikan oleh naluri yang irasional.

\subsection{Solusi Terhadap Permasalahan Simbolisme}

Adanya bahaya bahwa simbol dapat membawa pada fanatisme diri diperluas dan menjadi berhala membuat kita harus memegang teguh anikonisme dari ajaran Islam.Anikonisme menuntut manusia untuk membuat penilaian bukan berdasarkan ikon seperti warna kulit, keturunan, suku, bentuk pemerintahan, atau asal daerah, tetapi pada esensi dari perbuatan.Anikonisme mendorong kita untuk menggunakan akal untuk memperoleh kebenaran yang otentik dengan diri manusia.Kebenaran otentik ini tidak dapat dimanipulasi karena langsung ke pokok permasalahan dengan panduan yang jelas dari Al-Qur'an yang diberikan untuk manusia.Objektivitas kita terhadap alam menjadi landasan ontologis bagi penggunaan akal sebagai antitesis bagi simbolisme.Menurut kami, ada dua strategi dimana akal dapat digunakan menjadi prinsip evaluasi perbuatan dalam mencegah simbolisme, yaitu strategi horizontal dan strategi vertikal.

\subsubsection{Strategi Horizontal:} Keterbukaan Bumi menunjukkan pentingnya keanekaragaman.Keanekaragaman

memungkinkan sebuah kelompok untuk dapat bertahan dengan fitur-fitur yang dapat bertahan pada satu kondisi, sementara fitur lainnya gagal. Sebagai ilustrasi, jika dalam sebuah kelompok terdapat 100 orang dengan karakteristik berbeda dan terjadi sebuah kondisi lingkungan yang menyebabkan orang dengan karakteristik tertentu punah, masih ada sebagian yang akan selamat karena tidak memiliki karakteristik tersebut. Keberadaan orang-orang ini menjamin kelompok tersebut tetap lestari di kemudian hari.Intinya adalah, keanekaragaman menjamin kelangsungan hidup bersama dalam lingkungan ruang dan waktu. ${ }^{30}$ Intinya, keanekaragaman adalah rahmat.Manfaat ini, walau begitu, tidak dapat dicapai jika setiap anggota dalam kelompok saling menihilkan satu sama lain. Setiap anggota berusaha menghancurkan anggota lainnya dalam kelompok sehingga menurunkan keanekaragaman. Perilaku ini adalah perilaku bunuh diri yang membuat kelangsungan hidup keseluruhan kelompok terancam. Dalam kasus artikel ini, kelompok total tersebut adalah umat Islam dan anggota-anggota tersebut adalah berbagai golongan yang silang pendapat mengenai suatu masalah.

Sangat wajar jika manusia menyebar, membentuk golongan-golongan tertutup yang memberikan batas yang tegas mengenai golongan dalam dan luar.Sepanjang sejarah, manusia menyebar di muka bumi, menempati kawasankawasan kosong, lalu membangun masyarakat dengan bahasa dan adat istiadat tersendiri. Golongan-golongan ini dapat mengklaim bahwa budaya yang digunakannya diambil langsung dari sumber asli dan berperang dengan golongan lain. Hal ini berdampak pada menurunnya kelangsungan hidup keseluruhan.

Adanya golongan-golongan yang saling mematikan keanekaragaman di atas dapat dilihat pada Firman Allah berikut:

\footnotetext{
${ }^{30}$ Nathalie Seddon et al., 'Biodiversity in the Anthropocene: Prospects and Policy', Proceedings of Royal Society B 283, no. 20162094 (2016): 4.
} 
QS Ar-Rum [30]:31-32. dengan kembali bertaubat kepada-Nya dan bertakwalah kepada-Nya serta dirikanlah shalat dan janganlah kamu Termasuk orang-orang yang mempersekutukan Allah, Yaitu orang-orang yang memecah-belah agama mereka dan mereka menjadi beberapa golongan. tiap-tiap golongan merasa bangga dengan apa yang ada pada golongan mereka.

Sejalan dengan hal ini, terdapat pula hadist yang mengatakan:

Dan sungguh ummat Islam ini akan pecah menjadi 73 golongan. 72 golongan di neraka, dan 1 golongan di surga!". Para sahabat berkata: "Wahai Rasulullah siapakah yang 1 golongan ini?". Beliau menjawab: "apa yang aku dan para sahabatku berada di atasnya". (HR. Ahmad bin Hambal dan Abu Dawud) ${ }^{31}$

Hadist di atas menimbulkan pertanyaan mengenai siapa satu golongan yang masuk surga tersebut. Masing-masing akan mengklaim bahwa mereka berpijak pada ajaran Nabi dan para sahabat sehingga masih belum jelas eksistensi kaum yang masuk ke dalam surga.

Secara psikologis, hadist di atas menimbulkan pula kesan bahwa golongan yang masuk Islam sangat sedikit.Walau begitu, jumlah golongan tidak berkorelasi dengan jumlah pengikut.Masing-masing golongan yang masuk neraka dapat beranggotakan sedikit orang sementara golongan yang satu beranggotakan banyak sekali anggota, bahkan jauh lebih banyak dari gabungan anggota-anggota golongan lainnya tersebut. Seberapa banyak anggota golongan yang satu tersebut akan tergantung pada seberapa banyak orang yang masuk dan menerima premis dasar dari golongan tersebut.

Menurut kami, premis dasar dari golongan yang satu tersebut adalah

31 AAM bin Y Al-Qazwani, Sunan Ibnu Majjah (Jakarta: Gema Insani Press, 2016), 3992. keterbukaan. Hal ini karena keterbukaan memungkinkan satu golongan menerima golongan-golongan lainnya dan mengambil yang terbaik dari golongan lain untuk digunakan menghadapi situasi lingkungan. Manfaat kelangsungan hidup yang diperoleh kemudian disebarkan ke dalam golongan-golongan yang ada sehingga golongan yang terbuka semakin banyak. Kebahagiaan yang diperoleh akan di-copy ke golongan-golongan lainnya. Pada situasi yang ideal, semua golongan akan terbuka dan kebahagiaan satu golongan akan menjadi kebahagiaan dari golongan yang lain pula. Hal ini berbeda dengan golongan tertutup dimana kebahagiaan dari satu golongan justru akan menjadi kecemburuan lainnya.

Gambar 2 mengilustrasikan posisi golongan terbuka dibandingkan golongan tertutup.Golongan terbuka terlihat sebagai sebuah himpunan yang besar dan bergaris putus-putus sementara golongan tertutup memiliki garis batas yang padat.Ketika golongan tertutup masuk ke dalam golongan terbuka, golongan terbuka mengikis batas-batas tersebut sehingga batas-batas golongan tertutup mencair dan lebih terbuka.Golongan yang terbuka tidak harus satu karena seiring berjalannya waktu, golongan-golongan lain juga akan menjadi terbuka.

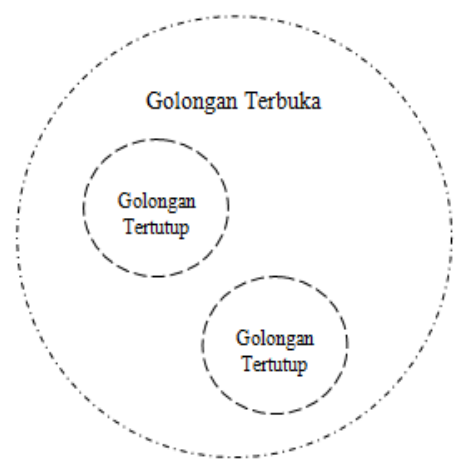

Gambar 2 Ilustrasi Golongan Terbuka dan Tertutup

Golongan yang terbuka adalah golongan yang merangkul golongan lainnya lewat tindakan-tindakan kolektif 
dan proaktif.Golongan ini mengutamakan diskusi sebagaimana didalilkan dalam QS. Al-Syura[42]:18 dan QS. Ali Imran[3]:159 dan mengutamakan silaturahmi. ${ }^{32}$

Tindakan kolektif adalah bentuk keterbukaan yang mengajak semua golongan lainnya untuk duduk bersama dan mencari solusi yang konstruktif atas suatu masalah dan membawa pada konsensus bersama yang dapat dipertanggungjawabkan secara akal maupu doktrinal.Pada kasus ulama yang berbicara kasar, keterbukaan diterapkan dengan mengajak semua pihak berdiskusi, termasuk di dalamnya ulama yang berbicara kasar tersebut, guna menggali niat dan menentukan nilai dari perbuatan tersebut.

Tindakan proaktif adalah bentuk keterbukaan yang dilakukan dengan mengunjungi satu per satu golongan untuk mencari solusi konstruktif tersebut.Kembali, pada kasus ulama yang berbicara kasar, keterbukaan proaktif diterapkan dengan mengunjungi ulama tersebut dan membahas permasalahan ini, saling tukar latar belakang dan pandangan, menggali niat yang dimungkinkan lewat analisis oleh akal, dan menentukan nilai perbuatan tersebut.

Keterbukaan pada gilirannya mencegah efek pecah belah yang ditimbulkan oleh simbolisme.Tafsir-tafsir dihadapkan kemuka dan dinilai secara logis dan doktrinal untuk menentukan nilai dari tafsir. Keterbukaan yang bersifat horizontal juga dapat bersifat vertikal jika pelaku menjadi salah satu partisipan dalam proses ini. Dengan adanya keterbukaan sebagai karakteristik kelompok, kita tidak akan bersenang-senang ketika kelompok lain bertikai dan saling bunuh. Sebaliknya, kita akan mengabaikan identitas simbolik

\footnotetext{
${ }^{32}$ QS Al-Nisa[4]:1; QS.
}

Muhammad[47]:22; QS. Al-Hujurat[49]:13; QS. Al-Nahl[16]:90 mereka dan menganggap mereka sebagai manusia yang patut mendapatkan empati dan simpati.

Masyarakat yang terbuka akan memandang bahwa keanekaragaman kelompok yang ada sebagai sebuah keunggulan yang memungkinkan adaptasi bersama dalam situasi yang berubah. Ketika situasi mengarah pada satu kondisi, terdapat kelompok yang bisa diandalkan sebagai kelompok yang menangani kondisi tersebut dan melindungi yang lain, begitu juga pada kondisi lainnya. Sebagai contoh, pada masa sebelum Revolusi Perancis, kelompok pemikir adalah kelompok yang maju ke depan dengan memberikan wacana-wacana pembebasan bagi masyarakat. Ketika kemelut politik telah sangat kritis bagi masyarakat, kelompok yang menjadi unggul adalah kelompokkelompok pergerakan yang bertindak tidak lagi menggunakan kata dan tulisan, tetapi lewat perbuatan langsung turun ke lapangan.Artinya, keanekaragaman menciptakan situasi yang saling melengkapi bagi alat-alat untuk kelangsungan hidup manusia.Kelompok pewacana dan kelompok pergerakan menjadi satu kesatuan utuh yang tangguh terhadap berbagai tantangan lingkungan dan menjadi adaptif dengan mudah.

Pentingnya penggunaan akal dapat ditarik langsung ke kisah Adam AS yang telah diceritakan sebelumnya.Sementara Iblis menolak Adam AS atas alasan yang emosional, para malaikat menggunakan analisis terhadap karakteristik Adam AS. Menurut para malaikat, Adam akan berbuat kerusakan di muka Bumi sehingga tidak layak untuk dihormati. Begitu pula, kita perlu mengedepankan analisis daripada emosional ketika menghadapi suatu masalah mengenai perbuatan di masa kini. Analisis ini merupakan aplikasi dari akal dan idealnya akan membawa pada analisis terhadap niat dari seseorang.

3.2.2 Strategi Vertikal : Evaluasi Niat 
Strategi vertikal adalah menyelidiki langsung ke momen historis pertama perbuatan tersebut, yaitu kemunculan niat. Dari Abu Hafsh bin Khathab ra berkata, Aku mendengar Rasulullah bersabda:

"Sesungguhnya amal-amal itu tergantung niatnya, dan setiap seseorang itu akan mendapatkan balasan sesuai dengan apa apa yang diniatkannya". ${ }^{33}$

Esensi dari hadistdi atas adalah bahwa perbuatan seseorang idealnya dievaluasi berdasarkan niat perbuatan tersebut dilakukan.Suatu perbuatan dapat merupakan perbuatan yang berniat dan perbuatan yang tidak diawali oleh niat.Perbuatan tanpa niat adalah perbuatan yang tidak disengaja dan perbuatan yang bersifat refleks.Pada awalnya, suatu perbuatan tidak diketahui apakah perbuatan tersebut diniatkan atau tidak tanpa adanya evaluasi. Jika evaluasi, misalnya dengan bertanya langsung, menemukan bahwa perbuatan tersebut adalah perbuatan yang diniatkan, maka dapat dilanjutkan apa niat tersebut. Evaluasi yang vertikal mengarah langsung ke niat akan mengklarifikasi secara objektif, nilai dari niat tersebut secara moral dan balasan atas konsekuensi behavioral dari niat tersebut dapat diberikan secara adil dan rasional. Hal ini menghindari reaksi seketika terhadap peristiwa yang dapat berupa kemarahan atau emosi lain yang mengarah pada simbolisme dan tidak menyelesaikan masalah.

Tapi mengapa berdasarkan niat, bukan berdasarkan hasil?Alasannya adalah suatu niat dapat menghasilkan dua hasil yang bertentangan, sementara di sisi lain, satu perilaku tidak dapat bersumber dari dua niat yang bertentangan karena niat yang bertentangan tidak dapat hadir dalam pikiran manusia, dalam artian niat tersebut

${ }^{33}$ IH Al-Asqalani, Fathul Bari (Jakarta: Pustaka Imam Asy-syafi'i, 2016), 15. dinilai bertentangan sepenuhnya dari aspek psikologis, bukan dari kesalahan persepsi yang muncul ketika perilaku dilakukan. ${ }^{34}$ Walau tidak seperti komputer yang akancrash jika memiliki dua program yang bertentangan, manusia tetap akan mengambil langkah ketika pada awalnya manusia memiliki dua niat yang bertentangan, yaitu manusia akan memilih salah satunya atau meninggalkan keduaduanya. ${ }^{35}$ Bahkan seandainya seseorang memiliki dua niat yang bertentangan, perilakunya hanya akan secara praktis konsisten dengan satu niat sementara dalam kondisi lain, konsisten dengan niat lain yang bertentangan tersebut. ${ }^{36}$ Karena alasan ini, kita dapat melihat niat sebagai prediktor perilaku.

Di sisi lain, dua perilaku yang bertentangan dapat muncul dari satu niat yang sama. Pertimbangkan misalnya orang-orang munafik yang dirujuk dalam ayat berikut: QS. Ali Imran[3]:119. Beginilah kamu, kamu menyukai mereka, Padahal mereka tidak menyukai kamu, dan kamu beriman kepada Kitab-Kitab semuanya.apabila mereka menjumpai kamu, mereka berkata "Kami beriman", dan apabila mereka menyendiri, mereka menggigit ujung jari antaran marah bercampur benci terhadap kamu. Katakanlah (kepada mereka).: "Matilah kamu karena kemarahanmu itu". Sesungguhnya Allah mengetahui segala isi hati.

Ayat di atas menunjukkan kalau satu niat, yaitu kebencian pada umat Islam,

34 R Mena, 'A Bump in the Road', Manuscrito - Revista Internacional de Filosofia 43, no. 4 (2020): 182.

${ }^{35}$ D Morgan, 'Impersonal Intentions', The Philosophical Quarterly 68, no. 271 (2018): 9.

${ }^{36}$ Hein Duijf, J Broersen, and J-J C Meyer, 'Conflicting Intentions : Rectifying the Consistency Requirements', Philosophical Studies 176, no. 4 (2019): 1, https://doi.org/10.1007/s11098-0181049-z. 
dapat menghasilkan dua perilaku bertentangan.Pertama, mengatakan bahwa dirinya beriman.Kedua, marah dan benci pada orang beriman. Jika kita menilai sesuatu berdasarkan perbuatan, maka perbuatan mana yang akan dirujuk. Jika kita menggunakan perbuatan "menyatakan diri beriman" sebagai rujukan, kita salah mengklaim bahwa orang ini baik, karena pada momen lainnya, orang ini juga marah dan benci ketika kita tidak melihatnya.Artinya, adanya kemampuan manusia untuk bertindak munafik memungkinkan kita dihadapkan pada masalah jika kita mengevaluasi seseorang berdasarkan perilaku. Sebaliknya, jika kita menilai dari niat, maka kemunafikan tersebut akan terungkap, begitu juga ketulusan atau kejahatan. Ini pula mengapa dalam ayat di atas, Allah menyatakan diriNya mengetahui segala isi hati, merujuk pada aspek yang bersifat psikologis.

Teori perilaku terencanamenegaskan bahwa perbuatan seseorang ditentukan oleh dua faktor: niat dan kemudahan untuk berperilaku. $^{37}$ Para ahli di bidang manajemen menegaskan bahwa pengutamaan niat adalah faktor pembeda antara sistem etika Islam dan sistem etika lainnya. ${ }^{38}$ Etika Islam lebih menegaskan pada kemurnian niat, alih-alih hasil dari suatu perbuatan (Nasution \& Rafiki, 2020, hlm. 196).Hal ini memungkinkan perbuatan kerja keras yang tidak membuahkan hasil sekalipun, dapat diberikan nilai, sementara perbuatan yang bermanfaat tetapi sebenarnya diniatkan untuk kejahatan diberikan nilai yang

37 Reuven Sussman and Robert Gifford, 'Causality in the Theory of Planned Behavior', Personality and Social Psychology Bulletin 45, no. 6 (2019): 1.

38 J Mohammad and F Quoquab, 'Furthering the Thought on Islamic Work Ethic: How Does It Differ?', Journal of Islamic Marketing 7, no. 3 (2016): 359-361.
rendah.Pengutamaan niat membedakan etika Islam dari etika Protestan, sistem etika yang paling umum di dunia saat ini, yang mengutamakan pada hasil ketimbang niat. $^{39}$ Pengutamaan hasil daripada niat saat ini telah membawa pada kapitalisme yang lebih mengutamakan penumpukan kekayaan dan menciptakan kesenjangan besar dalam masyarakat. ${ }^{40}$

Kasus pertengkaran antar ulama yang belakangan terjadi dapat dijadikan contoh aktual, dimana satu ulama mengucapkan kata yang dianggap keras, kemudian direspon oleh ulama lain bahwa ulama harus berkata dengan sopan santun. Hal ini adalah sebuah masalah simbolisme karena terdapat permasalahan mengenai asosiasi antara ikon dan simbol yang perlu diperjelas.Ikon dalam masalah ini adalah ucapan.Simbol yang diangkat adalah moralitas.Ada sebuah asosiasi yang diasumsikan dan diterima benar oleh banyak orang, yaitu bahwa ucapan yang keras pasti jahat dan ucapan yang lembutpasti baik.

Asosiasi di atas harus diujikan kebenarannya pada dua sisi sekaligus: apakah ucapan yang keras berarti orang yang mengucapkannya jahat dan apakah ucapan yang lemah lembut berarti orang yang mengucapkannya baik. Hal ini tentu meningkatkan beban kognitif dan sama sekali tidak memecahkan masalah. Alihalih mempermasalahkan sesuatu yang ada dibalik ucapan tersebut, masyarakat dan ulama justru bertengkar mengenai masalah simbol yang bersifat tampak, daripada menggunakan akal untuk mengidentifikasi motif yang tidak tampak.Lebih dari itu, hal ini menimbulkan bahaya bahwa seseorang

39 R Arzu Kalemci and IK Tuzun, 'Understanding Protestant and Islamic Work Ethic Studies: A Content Analysis of Articles', Journal of Business Ethics 158, no. 4 (2019): 8.

40 Benjamin Kirby, 'Pentecostalism , Economics , Capitalism: Putting the Protestant Ethic to Work', Religion 49, no. 4 (2019): 582. 
dianggap baik karena berbicara sopan dan orang yang berbicara sopan menganggap dirinya baik.

Pengutamaan niat lebih baik dari pengutamaan simbol karena menghindari asumsi-asumsi serta efek-efek negatif tersembunyi yang melekat pada simbol dan penggunaan kekuasaan untuk memaksakan dengan langsung pada sumber pertama dari perbuatan.Kita tidak akan terjebak pada masalah yang lebih kompleks akibat kemunculan simbol tandingan. Sebagai contoh, pada kasus perdebatan ulama, kita dapat menanyakan langsung niat ulama yang berkata kasar ketimbang berdebat bahwa ulama yang baik berbicara lembut dan ulama yang buruk berbicara kasar.Jika misalkan diketahui bahwa niat ulama tersebut adalah karena marah pada kritik terhadapnya, maka dapat ditarik hikmah bahwa ulama tersebut bersifat responsifdan bahwa respon seperti ini tidak boleh ditiru oleh umat karena tidak efektif dan tidak murni karena Allah.Secara pribadi kita dapat memaafkan, sementara setiap dari kita tetap memiliki tanggungjawab moral untuk saling mengingatkan sebagaimana dinyatakan dalam Al-Qur'an surah al-Asr. Hal ini tentunya lebih baik daripada harus berhadapan dengan masalah baru ketika ulama lain menekankan sopan santun (ketimbang niat).dan aspek-aspek behavioral yang berpotensi mendua karena adanya kemampuan manusia untuk munafik.

Keunggulan lain dari analisis terhadap niat adalah bahwa kita dapat mengungkapkan adanya niat baik dengan hasil yang buruk. Kondisi ini adalah kebalikan dari adanya niat jahat dengan hasil yang mendua, seperti pada kasus kemunafikan.Ia tidak berlawanan dengan niat jahat yang memiliki hasil yang baik karena ini berarti hal yang patut disyukuri. Niat jahat yang memiliki hasil yang mendua harus dihilangkan untuk memperjelas kedudukan perilaku.Niat baik ynag memiliki hasil yang buruk harus diperbaiki agar hasil menjadi baik oleh umat dengan memberikan saran berperilaku yang benar atau menyediakan dukungan agar perilaku tersebut terlaksana dengan lancar.Contoh adalah bagaimana seorang pemimpin paternalistik berniat memajukan umat tetapi justru umat menjadi terpecah belah. ${ }^{41}$ Dalam hal ini, umat harus memerbaiki cara atau paradigma orang tersebut dan memberikan dukungan moril dan fisik agar niatnya dapat memberikan hasil yang positif.

Inti dari solusi yang kami berikan adalah bahwa manusia saat ini harus beranjak lebih dalam dari sekedar mengamati sesuatu yang tampak, tetapi lebih dalam ke aspek-aspek tak tampak yang banyak terdapat dalam kehidupan sehari-hari.Bahkan wabah Covid-19 saat ini juga sudah memberikan kita petunjuk pentingnya mempertajam akal kita untuk mengeksplorasi hal-hal yang tidak terlihat.Berbeda dengan wabah-wabah terdahulu yang memiliki manifestasi tampak yang unik, Covid-19 memiliki manifestasi tampak yang sama dengan flu biasa. Hanya dengan analisis kita dapat mengetahui bahwa hal tersebut memiliki akar yang jauh lebih berbahaya dari penampilannya. Begitu pula, kita perlu untuk terbuka akan hal-hal yang tak tampak dan memulai analisis yang mendalam guna membongkar niat dibalik perilaku dan mengambil solusi-solusi yang mengakar, ketimbang pseudo-solusi yang hanya menambah permasalahan.

\section{Kesimpulan}

Berdasarkan pada argumentasiargumentasi di atas, dapat ditarik

41 H Aviram, "What Were " They " Thinking, and Does It Matter? Structural Inequality and Individual Intent in Criminal Justice Reform', Law and Social Inquiry 45, no. 1 (2020): 2 . 
kesimpulan bahwa simbolisme adalah sebuah permasalahan purba yang terjadi bahkan semenjak Nabi Adam AS diciptakan.Sepanjang sejarah, kecenderungan simbolisme telah dimanfaatkan oleh kekuatan politik maupun sosial dalam berbagai kepentingannya.Hal ini menunjukkan bahwa simbolismemerupakan naluri primordial manusia dalam hidup di dunia.Kami menunjukkan bahwa sifat sosial manusia yang berusaha berkumpul dalam kelompok yang dipimpin oleh seorang alpha dan kecenderungan personifikasi alam menjadi akar evolusioner dari permasalahan simbolisme.Nabi dan rasul dari semenjak Adam hingga Muhammad SAW berjuang untuk mengalahkan simbolisme. Jika simbolisme dipertahankan, maka akan membawa pada syirik dengan menjadikan simbol sebagai berhala bagi manusia. Hal ini memecah belah umat karena dua hal.Kedua, bahwa simbolisme memungkinkan pihak ketiga untuk memanfaatkan simbol untuk tujuan-tujuan batil yang merusak persatuan umat dan iman masyarakat.Ajaran Islam secara garis besar adalah ajaran yang meminta para penganutnya untuk menolak simbolisme yang tampak demi pengutamaan akal, sebagai modal manusia untuk mampu bertindak bebas di dunia.Tetapi karena simbolisme memakan lebih sedikit energi dibandingkan berpikir, maka banyak manusia menggunakan simbolisme sebagai justifikasi perilaku, alih-alih menggunakan akalnya secara optimal.Objektivitas adalah sebuah karakteristik dari pemikiran berbasis akal dan ini dapat dicapai dengan menjaga keterbukaan pikiran dari berbagai perspektif yang dapat muncul.Keterbukaan, yang diwujudkan dalam silaturahmi, memungkinkan akal menemukan titik-titik kesamaan ataupun menemukan solusi atau penjelasan yang paling logis yang dapat
diterima.Keterbukaan akan membawa pada niat yang menyentuh akar masalahsehingga menjamin agar umat tidak terpecah dan karenanya, mencegah efek buruk dari simbolisme.

Tantangan umat manusia ke depan bukan lagi tantangan secara visual, seperti kegelapan, harimau, atau suara-suara keras, tetapi perpecahan, fitnah, virus, adu domba, korupsi, kemunafikan, dan hal-hal lain yang tidak lagi terlihat. Pada situasi seperti ini, simbolisme tidak lagi dapat digunakan.Situasi tantangan yang bersifat tak tampak memerlukan analisis yang menggunakan akal yang membawa pada keterbukaan dan upaya untuk mencari niat. Walau begitu, akan ada kekuatan-kekuatan tak tampak yang menghalangi penggunaan akal dengan menarik manusia ke arah naluriahnya menggunakan simbol-simbol dengan upaya mengadu domba manusia. Musuh berusaha menarik manusia ke titik terendahnya yang sub optimal di bawah akal, yaitu kebertopangan pada aspekaspek tampak yang memicu emosional.Karena setiap orang memiliki potensi menggunakan akal untuk analisis, maka upaya pemanfaatan akal untuk mengatasi masalah kemanusiaan perlu terus dipertajam dan digalakkan.

\section{DAFTAR PUSTAKA}

Al-Asqalani, IH. Fathul Bari. Jakarta: Pustaka Imam Asy-syafi'i, 2016.

Al-Qazwani, AAM bin Y. Sunan Ibnu Majjah. Jakarta: Gema Insani Press, 2016.

Aviram, H. "What Were " They" Thinking , and Does It Matter? Structural Inequality and Individual Intent in Criminal Justice Reform'. Law and Social Inquiry 45, no. 1 (2020): 249263.

Barham, Lawrence, and D Everett. 'Semiotics and the Origin of Language in the Lower Palaeolithic'. 
Journal of Archaeological Method and Theory (2020).

Barzun, Charles L. 'The Genetic Fallacy and a Living Constitution'. Constitutional Commentary 34 (2019): 429-462.

Bruni, Domenica, Pietro Perconti, and Alessio Plebe. 'AntiAnthropomorphism and Its Limits'. Frontiers in Psychology 9, no. 2205 (2018): 1-9.

Carlson, Matt. 'The Information Politics of Journalism in a Post- Truth Age'. Journalism Studies 19, no. 13 (2018): 1879-1888.

https://doi.org/10.1080/1461670X.201 8.1494513.

Clasen, M. 'Evolutionary Study of Horror Literature'. In The Palgrave Handbook to Horror Literature, edited by $\mathrm{K}$ Corstorphine and $\mathrm{L}$ Kremmel. London: Palgrave Macmillan, 2018.

Dogan, Recep. 'The Soul's Need to Connect with God through the Language of Art: Analysis from an Islamic Perspective'. Review of European Studies 10, no. 2 (2018): 60-67.

Duijf, Hein, J Broersen, and J-J C Meyer. 'Conflicting Intentions: Rectifying the Consistency Requirements'. Philosophical Studies 176, no. 4 (2019): 1097-1118. https://doi.org/10.1007/s11098-0181049-z.

Eder, A-M A, Lawler Raphael, and R van Riel. 'Philosophical Methods under Scrutiny: Introduction to the Special Issue Philosophical Methods'. Synthese 197, no. 3 (2020): 915-923. https://doi.org/10.1007/s11229-01802051-2.

Egler, Miguel, and Lewis D Ross. 'Philosophical Expertise under the Microscope'. Synthese 197, no. 3 (2020): 1077-1098. https://doi.org/10.1007/s11229-0181757-0.

Epley, Nicholas. 'A Mind like Mine: The Exceptionally Ordinary Underpinnings of Anthropomorphism'. Journal of the Association for Consumer Research 3, no. 4 (2018): 591-598.

Febriana, Widia, and Tayo Sandono. 'Relativisme Determinatif: Akal, Sistem , Dan Waktu Sebagai Komponen Quranik Untuk Optimalisasi Hidup Manusia'. Aqlania: Jurnal Filsafat dan Teologi Islam 11, no. 2 (2020).

Greenberg, Raz. 'How Animation Won Over the Lightning Sketch: ReEvaluating Humorous Phases of Funny Faces'. Animation: An Interdisciplinary Journal 13, no. 2 (2018): 162-174.

Hansen, Pelle G, Vincent F Hendricks, and RK Rendsvig. 'Infostorms'. Metaphilosophy 44, no. 3 (2013): 301-326.

Harahap, J. 'Sayyed Hossein Nasr Tentang Filsafat Perennial Dan Human Spiritualitas'. Aqlania: Jurnal Filsafat dan Teologi Islam 08, no. 02 (2017): 173-196.

Hunt, Laurence T, Robb B Rutledge, W M Nishantha Malalasekera, W Kennerley, and Raymond J Dolan. 'Approach-Induced Biases in Human Information Sampling'. PloS Biology 14, no. 11 (2016): 1-23.

Kalemci, R Arzu, and IK Tuzun. 'Understanding Protestant and Islamic Work Ethic Studies: A Content Analysis of Articles'. Journal of Business Ethics 158, no. 4 (2019): 999-1008.

Kiernan, P. Roman Cult Images : The Lives and Worship of Idols from the Iron Age to Late Antiquity. Cambridge: Cambridge University Press, 2020.

Kirby, Benjamin. 'Pentecostalism , 
Economics, Capitalism: Putting the Protestant Ethic to Work'. Religion 49, no. 4 (2019): 571-591.

Lackovic, N. 'Thinking with Digital Images in the Post-Truth Era: A Method in Critical Media Literacy'. Postdigital Science and Education 2 (2020): 442-462.

Leach, Colin Wayne. 'Understanding Shame and Guilt'. In Handbook of the Psychology of Self-Forgiveness, edited by Lydia Woodyatt, Ev Worthington, Michael Wenzel, and Brandon Griffin, 1-24. New York: Springer, 2017.

Leroy, Frederic;, Malaika; Brengman, Wouter; Ryckbosch, and Peter Scholliers. 'Meat in the Post-Truth Era . Mass-Media Discourses on Health and Disease in the Attention Economy'. Appetite 125 (2018): 345355.

Mena, R. 'A Bump in the Road'. Manuscrito - Revista Internacional de Filosofia 43, no. 4 (2020): 177-188.

Michaud, Nicolas. 'Inappropriate Appeal to Authority'. In Bad Arguments: 100 of the Most Importan Fallacies in Western Philosophy, edited by R Arp, S Barbone, and M Bruce, 168-171. Oxford: Wiley Blackwell, 2019.

Mohammad, J, and F Quoquab. 'Furthering the Thought on Islamic Work Ethic: How Does It Differ?' Journal of Islamic Marketing 7, no. 3 (2016): 355-375.

Morgan, D. 'Impersonal Intentions'. The Philosophical Quarterly 68, no. 271 (2018): 376-384.

Morsky, Bryce, and Erol Akcay. 'Evolution of Social Norms and Correlated Equilibria'. PNAS 116, no. 18 (2019): 1-7.

Nasution, Fahmi Natigor, and Ahmad Rafiki. 'Islamic Work Ethics, Organizational Commitment and Job Satisfaction of Islamic Banks in
Indonesia'. RAUSP Management Journal 55, no. 2 (2020): 195-205.

Pierce, JL, and J Peck. 'The History of Psychological Ownership and Its Emergence in Consumer Psychology'. In Psychological Ownership and Consumer Behavior, edited by Joann Peck and Suzanne B Shu, 1-18. Cham, Switzerland: Springer, 2018.

Sardar, Ziauddin. 'The Smog of Ignorance: Knowledge and Wisdom in Postnormal'. Futures 120 (2020): $1-12$.

https://doi.org/10.1016/j.futures.2020. 102554.

Scalambrino, F. 'Genetic Fallacy'. In Bad Arguments: 100 of the Most Importan Fallacies in Western Philosophy, edited by $\mathrm{R}$ Arp, $\mathrm{S}$ Barbone, and $\mathrm{M}$ Bruce, 160-162. Oxford: Wiley Blackwell, 2019.

Scheepers, Floortje E, Jos de Mul, Frits Boer, and Witte J Hoogendijk. 'Psychosis as an Evolutionary Adaptive Mechanism to Changing Environments'. Frontiers in Psychiatry 9, no. 237 (2018): 1-6.

Seddon, Nathalie, Georgina M Mace, Shahid Naeem, Joseph A Tobias, Alex L Pigot, Rachel Cavanagh, David Mouillot, James Vause, and M Walpole. 'Biodiversity in the Anthropocene : Prospects and Policy'. Proceedings of Royal Society B 283, no. 20162094 (2016): 1-9.

Srinivasan, Saurabh, Francesco Bettella, Oleksandr Frei, W David Hill, Yunpeng Wang, Aree Witoelar, Andrew J Schork, et al. 'Enrichment of Genetic Markers of Recent Human Evolution in Educational and Cognitive Traits'. Scientific Reports 8, no. 12585 (2018): 1-9.

Suhaeni, E. 'Manusia Dan Ancaman Covid-19 Dalam Perspektif AlQur'an'. Rausyan Fikr 16, no. 2 (2020): 108-117. 
Sussman, Reuven, and Robert Gifford.

'Causality in the Theory of Planned

Behavior'. Personality and Social

Psychology Bulletin 45, no. 6 (2019): 920-933.

Tager, A. "The Triple "I " and the Human Eye: Three Phases of Evolution in Vision and Thinking'. New Zealand Online Journal of Interdisciplinary Studies 1, no. 3 (2019): 72-94.

Tantray, Mudasir Ahmad, Tariq Rafeeq Khan, and ID Rather. 'Nature of Analytical Philosophy'. Ravenshaw Journal of Philosophy 6 (2020): 1631.

Taylor, P, J N Hobbs, J Burroni, and H T Siegelmann. 'The Global Landscape of Cognition: Hierarchical Aggregation as an Organizational Principle of Human Cortical
Networks and Functions'. Scientific Reports 5, no. 18112 (2015): 1-18.

Valdivia, Pablo. 'Narrating Crises and Populism in Southern Europe : Regimes of Metaphor'. Journal of European Studies 49, no. 3-4 (2019): 282-301.

Warjo, Vita Dhameria, and Judiman. 'Agama Islam Sebagai Tata Nilai Kehidupan Bisnis Ber-Etika'. Cendekia Jaya 1, no. 2 (2019): 59-72. 
Keterbukaan Dan Niat: Refleksi Terhadap Gejala Simbolisme Dalam Masyarakat Islam PascaKebenaran 